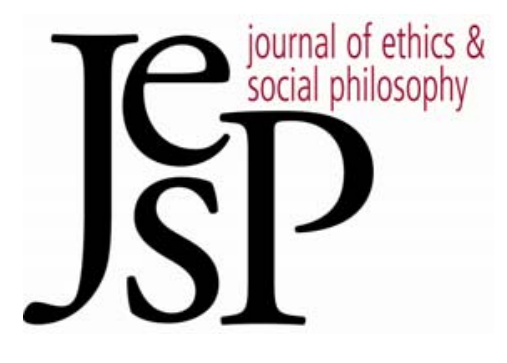

\title{
REPLY TO CRITICS OF THE CONSTITUTION OF EQUALITY
}

\author{
BY THOMAS CHRISTIANO
}

Journal of Ethics \& Social Philosophy

SYMPOSIUM I| AUGUST 2011

URL: WWW.JESP.ORG

COPYRIGHT (C) THOMAS CHRISTIANO 2011 


\title{
Reply to Critics of The Constitution of Equality
}

\author{
Thomas Christiano
}

Constitution of Equality challenge the theses of the book on a number of
counts: the proper relation of democracy to judicial review, the issue about what kind of group democratic principles are properly applied to, and the relation between democracy and democratic deliberation to serious injustice. I am pretty sure that I have not done complete justice to any one of these careful and probing criticisms but I hope to answer each of them in a way that provides some basis for further discussion. I will take them each in turn.

\section{Brettschneider's Comments}

Corey Brettschneider's challenging remarks come out of his own deeply considered conception of democratic authority and its limits. Ultimately his worry is that I give too much room for non-democratic institutions such as judicial review. He thinks I give too much latitude to courts that review democratic legislation and that I may be sacrificing the intrinsic value of democracy.

\section{The Nature of the Limits to Democratic Authority}

Corey Brettschneider worries that my account of democracy is grounded in a controversial and sectarian idea of public equality. Since this idea of public equality is meant to ground limits to democratic decision-making and may license courts to enforce these limits, he worries that the conception of judicial review I offer in effect endows the judiciary with the power to knock down democratic decisions on the basis of this controversial and sectarian idea of public equality. This seems to him to license a highly activist court that attempts to promote comprehensive or sectarian values when it thinks that the democratic assembly is failing to do so.

It will be useful here to sketch my account of public equality and the role of this political principle in regulating a political society. My idea is that the purpose of political society is to attempt to establish justice among persons within that society by means of law and policy. In my book, I argue that the principle of equality of advancement of interests is the guiding principle of justice. I defend and articulate this principle in chapter 1. But conflicts of interest and disagreement about the common good and justice characterize political societies. This implies that persons will disagree on how to treat each other as equals in political society. So they will disagree on how best to establish justice through law and policy. I defend the idea that persons have fundamental interests in having their judgments concerning justice and the common good respected when they disagree on justice. I argue in chapter 2 on the basis of the principle of equality and a conception of the fundamental 
interests of persons that when a political society attempts to realize equality among its members it must do so in a way that each can see that the society is treating them as equals. This is the principle of public equality. It requires in effect that a society be regulated by principles that everyone can see treat them as equals. So the basic question is, how can persons treat each other as equals in a political society in a way that each can see that they are treated as equals, when there is so much disagreement about justice and the common good? My answer is that, when there is disagreement about how to organize society justly and how to live a good life, people can nevertheless treat each other in ways that treat them publicly as equals if the disagreements about law and policy are resolved through robustly democratic decision-making and if disagreements about how to live one's life are resolved within the context of robust liberal rights of freedom of conscience, freedom of association, freedom of expression and privacy. They must also have a minimum of economic resources as well. In my book, I argue in some detail for each of these principles as principles of public equality. I devote chapter 3 to showing that democracy is a public realization of equality and chapter 4 to the thesis that liberal rights are public realizations of equality. I will not rehearse these arguments here. But it is important to see that the principles of democracy, liberal rights and economic minimum are public principles and that they serve as the egalitarian framework for decision-making in a political society. Within the framework determined by these principles, persons may attempt to advance their more particular and controversial conceptions of equality (in law and policy) and may advance their particular and controversial conceptions of how to live. So if a society is democratic, liberal and guarantees an economic minimum, despite all the disagreements that people have, they will nevertheless be able to see that the society treats them as equals in a publicly clear way. The principles of democracy, liberal rights and economic minimum are public principles that are the minimum necessary and sufficient conditions for public equality. Public equality is in this sense a minimum set of standards that serve as an egalitarian framework for the rest of social life. The principles of public equality cannot reach much further than this because they would then become too controversial as realizations of equality. So the idea is that public equality is not a sectarian notion but one that implies a certain kind of agreement among members of the society. I think we see this kind of agreement in contemporary advanced liberal democracies, though these societies still fall far short of the ideals they profess.

My idea then is that the principle of public equality is the moral ground of democracy and the moral ground of liberal rights and an economic minimum. I argue that, since the same principle grounds both democracy and liberal rights, it can provide grounds for the authority of democracy and for the limits to democratic authority. The argument for the limits to democratic authority can be sketched very simply without too much distortion. A democratic assembly realizes public equality by giving each an equal say in the process of collective decision-making. This is the sense in which democracy has 
intrinsic value. It just is a realization of public equality. A necessary part of this realization is the fact that making decisions democratically expresses the equality of all members of political society. But a decision of a democratic assembly defeats this expressive character of democracy when the legislation made clearly undermines public equality. And so it defeats the expressive character of democracy when the democratic assembly knowingly passes legislation that violates the core of democratic or liberal rights. In this case democracy no longer realizes public equality. The authority of democracy, I argue in chapter 6 , is grounded in the fact that it realizes public equality. From these premises, I argue in chapter 7 , it follows that the authority of democracy is defeated when it violates the core of democratic or liberal rights. It is defeated because a necessary condition of democracy realizing public equality is absent. It is for this reason that violation of the core of democratic or liberal rights undercuts the authority of democracy.

Now I argue that under the right conditions a system of judicial review of legislation that empowers the judiciary to strike down legislation that violates public equality can be legitimate. This is because a decision of the democratic assembly that violates public equality has no value, so a court that strikes it down will at least have the value that it preserves public equality. Thus the value of judicial review is instrumental and so for me the question here is primarily an empirical one. The question is: does some kind of judicial review reliably strike down legislation that violates public equality and reliably let pass legislation that does not violate public equality? If the answer to both these questions is yes (and I am not sure that it is yes for the United States), then the legitimacy of judicial review is established. Furthermore, it should be noted that this allows for fairly careful tailoring of institutions of judicial review for the particular political and social conditions under which it occurs.

There are two points to note here about this idea. One, public equality is a minimal requirement of justice, and, two, it involves a kind of consensus on equality. From these two observations we can see that the idea cannot be stretched very far. If it is stretched too far, it loses its character as a reasonably uncontroversial realization of equality. And we can see that the idea is inherently not a sectarian idea. Indeed I argue that it can only include democratic and liberal rights along with an economic minimum. Hence the limits to legitimate judicial review are quite severe though, in different societies, there may be empirical grounds for having more or less judicial review.

\section{Brettschneider's Concerns}

Brettschneider worries about my account of democratic authority. I argued in my book that democratic authority could be undermined in a number of different ways. The limits to democratic authority are external or internal in the sense that the limits are derived from principles distinct from those that underpin democracy or the limits are derived from the same principles that ground democracy. My focus in the book is on internal limits to democratic 
authority. In some cases of democratic authority I argue that violation of some principles undercuts the authority of democracy and, in some cases, violation of limits simply provides countervailing considerations to the fact that a decision has been made democratically. In particular, I argue that the violation of principles that underpin democracy undercuts the authority of democracy and thus annuls any obligation or duty to obey the decision. I also argue that in these contexts a court with powers of judicial review may conceivably be a defensible way to stop an assembly from violating limits.

Brettschneider gives a number of arguments for thinking that this is not so. He worries that I have sacrificed the idea that democracy has intrinsic worth. He thinks that I may be committed to an instrumental understanding of the grounds of democracy if I argue that the intrinsic justice and authority of democracy are undercut entirely by decisions that clearly violate public equality. He argues that the claim that democracy has intrinsic value favors the idea that the limits to democratic authority must always be countervailing considerations to be balanced against the value of democratic decisionmaking.

It is one of the main aims of my book to show in what way democratic decision-making is an intrinsically just way of making collective decisions in certain contexts. So this would be a very serious criticism of my account of the limits of authority.

But first, I do not think that the fact that democratic decision-making may have no authority in the case of clear violations of public equality commits me to an instrumental understanding of the grounds of democracy. At most it commits me to an account of the justice and authority of democracy as conditional. As Christine Korsgaard has noted, one can think that something is intrinsically valuable without thinking that it is unconditionally valuable. It can be intrinsically valuable in the sense that its value does not derive from the fact that it produces certain outcomes. ${ }^{1}$ It can be aimed at for its own sake. But it may be conditional in the sense that certain conditions negate its value. We might think that pleasure is of this sort. Pleasure is usually thought to be intrinsically valuable but the pleasure of the sadist may for all that still not be thought to be valuable at all. It is intrinsically valuable only under certain conditions. We might say that promise-keeping is intrinsically valuable normally but not unconditionally valuable as in the case of a promise to do something seriously immoral. It seems to me that these two cases can be replicated in a variety of contexts of value and they have a similar structure as the value of democracy and its defeat. In both these cases, the normally intrinsically valuable thing is not intrinsically valuable because it is deeply connected with something else, usually some kind of serious immorality. To be clear, I do not want to suggest that I think that this is the right account of these two values. I merely want to point out the conceptual coher-

${ }^{1}$ See Christine Korsgaard, "Two Distinctions in Goodness," in Creating the Kingdom of Ends (Cambridge: Cambridge University Press, 1996). 
ence of conditional intrinsic value. So I do not see any basic conceptual barrier to claiming that democracy can lose its intrinsic value in those contexts in which it violates in a publicly clear way the principles that underpin it.

I do not think it is right to say that the fact that the authority of democracy is undercut when it violates public equality shows that democracy is merely instrumental in protecting public equality. Public equality is merely a constraint on democracy. And it is merely the standard for the framework of social and political life. It determines only a small proportion of the issues that are evaluated in terms of justice. Much of law and social policy are justified in terms of not fully public principles; they are based on controversial principles. Democratic citizens aim at the common good and justice in legislation even though they know that their particular conceptions are controversial and thus not fully public conceptions of the common good and justice. The principle of public equality just says that they must pursue the realization of these non-public principles within the framework of institutions justified by public equality.

Brettschneider worries that my account implies that nothing is lost if a set of liberal or democratic rights is protected by the decision of a court acting against a democratically made decision. He thinks that I must be committed to the idea that, as long as the authority of democratic decision-making is undercut by some of its decisions, there is nothing lost in a court protecting the rights of persons. But I think we can see that something is lost when a court appropriately overturns a democratically made decision. It would have been better had the decision been properly made by the democratic assembly. My account allows for this to be the case. And this is because there is intrinsic if only conditional justice in democratic decision-making. Had the democratic decision been made properly it would have had this intrinsic justice. And this is something that a court can never have. So something is lost when a court must block the decision of a democratic legislature. However, I do agree with Brettschneider that on my view there is a sense in which nothing of value is lost when a court strikes down a decision that violates public equality. The particular deeply unjust decision, which may have been made in a democratic way, is itself negated and nothing of value is lost in its being negated. But this is perfectly compatible with the claim that it is worse that the minimally just decision was made by a court rather than by the democratic assembly. This seems to me to capture the intrinsic value of democracy but in a way that is compatible with the considerations that support the undercutting power of public violations of equality.

I would want to turn the tables a bit against Brettschneider and suggest that his countervailing or balancing account has counterintuitive implications. If there is always some weight in a decision that is made democratically, why is such a decision overridden by even minor but very clear violations of public equality? Suppose the legislature disenfranchises in some limited way a particular citizen, for example, by forbidding the citizen, who has done no wrong, from voting in an election or two. It is hard to see how, if the demo- 
cratic decision has weight by virtue of its having been made democratically, it could be outweighed by the importance of the one citizen voting in one or two elections. And thus, if democratic decisions always have weight, there must be some clear violations of public equality that are outweighed by it. But this seems to me to be precisely not the case. Even relatively small but very clear violations of public equality can justify overturning democratically made decisions. This is the kind of thing that an account of the limits of democratic authority ought to be able to explain and that the countervailing account cannot explain. So my thought is that the undercutting power of the limits of democratic authority gets these kinds of cases right and the merely countervailing account does not.

Brettschneider worries that I will not be able to explain the peculiar structure of civil disobedience if I argue that some democratic decisions generate no duties at all. The idea here is that a person who thinks a law is unjust and nonviolently disobeys the law may also be appropriately willing to submit to punishment for his open act of disobedience. And this, he thinks, suggests that the fact that the law has been made democratically has some weight despite its being unjust.

But I do not see this. The willingness to submit to punishment is often thought to be a sign of good faith opposition to the law and it is necessary to nonviolent opposition to the law. It may also be a sign of the general fidelity to law. I am not sure how Martin Luther King Jr. can be invoked in this context since he was advocating civil disobedience of laws that were unjust and that did not have particularly strong democratic credentials.

\section{Cindy Holder's Comments}

Cindy Holder raises three very probing and interesting questions for my views about democracy. The first question concerns the formation of societies and their boundaries. She queries the concept of common world that I have provided and examines its usefulness in political theory. Second, she worries about the fact that some societies have been created by force and fraud and that, despite these historical injustices, the later generations of victims have been required to go along with democratic decisions. Her concern stems from a concern for the self-determination of indigenous peoples, who seem to be forced to go along with democratic decision-making in my account.

Her third question is, what are the implications of my views about the authority of democracy for those who are not members of the democratic society in question? Do outsiders have duties to respect the democratic assembly's decisions? What kinds of duties are these? And what are they grounded in? She queries the implications of my principles of democracy for thinking about the international order.

I welcome these concerns because, though my book was not focused on these issues, they are very important ones and they are ones that I have been 
pursuing more in the last couple of years since I finished my book. The relationship of democracy to global justice has been uppermost in my work of late.

Nevertheless, I do think that the framework of social justice that I elaborate and defend in my book can be extended with some caution and with a lot of additional empirical knowledge to the global realm.

\section{The Common World}

The idea of a common world is the subject of some intriguing remarks Holder makes, to which I can only make partial replies. I define a common world as one "in which the fulfillment of all or nearly all of the fundamental interests of each person are connected with the fulfillment of all or nearly all of the fundamental interests of every other person." It is a kind of ideal type concept. The purpose of the idea is to define a very clear case of a social group in which individuals have reasonably equal stakes in how the society develops overall. My thought is that egalitarian methods of collective decision-making are particularly suitable and inherently just in social contexts in which people have equal stakes. And, since a common world is an instance of a world in which persons have equal stakes, democracy is an inherently just way of making collective decisions for it. It is of course only a sufficient condition. There are other social arrangements in which individuals have equal stakes in how they are disposed. But they are invariably less clearly ones in which equal stakes obtain. I argued that contemporary political societies are often common worlds because so much hangs on the common system of legislation, policy, courts, education and administration of public goods. They became common worlds partly because of the activities of the states in previous periods. The state does not constitute a common world; it is often historically the cause of the existence of a common world in its jurisdiction. This is what makes many contemporary states suitable sites for intrinsically just democratic decision-making. This is not meant to be an eternal truth nor is it meant to be the case that all states necessarily rule over common worlds. And, to repeat, the existence of a common world is not a necessary condition for democratic decision-making to be intrinsically just.

Holder makes a number of claims about the idea of a common world. One, she says that more than one common world may exist within a single state. Two, a state might comprise a number of overlapping common worlds. Three, the boundaries of common worlds are uncertain and shifting. Four, the multiplicity of common worlds suggests a justification for group rights. Five, that if there is a society in which there are discrete, mutually exclusive common worlds, then the peoples who live in these common worlds "would have no de facto mutuality compelling them, as a moral matter, to include one another in their decisions." (12)

I agree in significant part with the first three claims, with some qualifications. I do not know if I agree or disagree with the fourth. I very strongly 
disagree with the fifth claim, and that disagreement is essential in my view for thinking about international justice. I do agree that there is significant vagueness in the application of the concept of a common world. Who exactly is in a common world cannot be completely and determinately assessed. It is a group with fuzzy boundaries that are very different from the boundaries of the states that are usually quite clearly staked out. My hope is that the fuzziness is not so great as to make the concept useless. My thought is that many political societies are inhabited by populations 80 percent to 90 percent of which are characterized by the definition of a common world. I also agree that states can in some sense preside over a number of common worlds. Clear cases of this are empires and very deeply divided federal states. In some cases the state institution does little more than exact tribute from the subunits and provide unified defense. This is clearly compatible with distinct common worlds, though many have interests in the common system. What I think is characteristic of modern states is that they tend to draw everyone into the legal, educational, infrastructural system in a reasonably unified way. Even federal states tend to centralize power over the long run. This is meant to be an empirical claim and it may not hold in all important cases. Reflection on when it does not hold will I think be very important for figuring out how to extend democratic principles to regional and then international institutions since these will inevitably need to have something like federal structures. As to the question of overlapping common worlds, I think that too has some plausibility, except it would seem to me that most cases of overlapping common worlds will actually be parts of a single common world. This is because the agent that creates the overlap - the state - affects a lot of different persons at the same time.

But I worry about possible confusion between the idea of a common world and other ideas that are quite different. Holder's discussion suggests some of the time that she is discussing something like a common culture or common nationality. The discussion of group rights and group selfdetermination suggests some notion of cultural or national groups. I meant in my book to distinguish the idea of a common world from the idea of a common nationality or culture. The first notion speaks to the interdependence of interests, which may result merely from people's actions impinging on each other. The notion of common nationality or culture suggests an attitudinal dimension to the commonality. People share certain attitudes and they know they share those attitudes. Some have thought that shared culture or shared nationality could form the basis of a collective right of selfdetermination. But I do not know if anyone would think that a group of persons has a collective right of self-determination by virtue of their interests being deeply interdependent. I think as a matter of fact that each person can claim a right to have a say in collectively decided matters in these circumstances. If that is sufficient for asserting that the group of people has a collective right of self-determination, I am happy to say that my argument in the book is an argument for collective self-determination. 
Finally, I do not agree with Holder that if persons are sorted into distinct common worlds then they have no de facto mutuality compelling them to include one another in their decisions. This suggests that, if persons inhabit separate common worlds, they have no common issues to decide, but this need not be. I take it that members of different states can have much to decide among themselves even if they do not inhabit common worlds. The reason for this is that they have some interdependence of interests, just not enough for a common world. Here I think a conception of fair international negotiation could help us think through what is necessary for a just resolution of conflicts of interest between persons who do not occupy the same common world. And, of course, it is possible that one day there will be democratic regional institutions ruling over at least some features of states. The European Union seems to aspire to do this, though it is clearly not democratic yet.

Perhaps the most important idea in Holder's discussion here is that the reality of social life to which democratic norms may or may not apply is messier than the idea of a common world suggests.

\section{Historical Injustice and Public Equality}

I agree with Holder that historical injustices pose special problems for a conception of democracy since on my account at least democracy starts from a conception of a community that is given. And, though I think that the arbitrariness of origins of a given community is not a basic problem for democracy, the fact that serious historical injustice is at the basis of some communities is sometimes a problem for thinking of these as communities of persons who ought to treat each other as equals.

The major case Holder has in mind is the case of indigenous peoples in the Americas. Here the history of injustice is appalling and makes any serious person pause when thinking about the legitimacy of the democratic societies that inhabit the Americas.

I have not given an account of how to deal with historical injustice in my book. My main purpose in applying democratic ideas to the case of indigenous peoples is to see how much these ideas can help us understand the sense that these peoples have been treated unjustly. But I have not addressed the moral question of appropriate remedy. Still I do think some interesting things can be said about it from the standpoint of the views I defend.

One, the injustices themselves can be explained in part on the basis of the democratic views I have defended. Conquest and subjection of one society by another are clearly violations of public equality. Indeed, one of the main issues Spanish thinkers faced in assessing the legitimacy of the conquest of America was precisely this question of equality. Those who advocated the conquest denied the equality of Native Americans and Christian Europeans and described the former as natural slaves, while those who questioned the conquest often did so on the grounds that Europeans and Native Americans 
were at least not fundamentally unequal.2 Second, as Holder notes, these injustices are ongoing. And I think that I can give an account of the nature of these ongoing injustices on the basis of the principles of public equality. The kinds of injustice Holder points to - namely that the interests of the Native American persons "are supposed to be deeply impacted by my interests and decisions, while my interests are supposed to be hardly impacted at all by her interests and decisions" - is a clear statement of violation of democratic principles on my account. I attempt to show that the same principles are in play in assessing the injustice involved in the existence of persistent minorities. I argue that an appropriate remedy to unalterable injustice and to persistent minority status is to grant partial autonomy to the group that is so treated or to grant it strong rights of consultation. ${ }^{3}$ Third, I think that much of my account captures the current state of international law regarding indigenous peoples. The remedy for persistent minority status is some kind of partial political autonomy or some system of consultation, which is the current proposed remedy in international law.4 So I do think that the principles I set out provide some significant guidance on how to think about the injustice that has been done to Native American peoples and it accounts in significant part for the remedies that have actually been offered.

Still, it is right to note that, while democratic and liberal principles may capture much of the injustice that occurs in colonization and conquest, they do not offer guidance in how to rectify past injustice. I have not tried to answer that question in the book, though I do hope that the more abstract principle of public equality, which is the ground of democracy and liberal rights, may provide more guidance even here. Certainly Holder is right that a complete account of the morality of democracy must include a discussion of this issue.

But I do want to express some skepticism about one of Holder's claims regarding historical injustice here. She says, "when a common world produced by a state is rife with wrongful connections the first priority would seem to be unwinding the web of wrongful connections and establishing different relationships and connections." (4) Of course I agree that a priority should be to establish rightful relations. But this is not what is intended. The metaphor of unwinding the web of wrongful connections suggests that the rectification of historical injustice, even if it happened a long time ago, is the first priority over even creating present justice. I tend to think of the rectification of past injustice as not as important as this phrase suggests. My

2 See Francisco de Vitoria, "On the American Indians," in Political Writings, Anthony Pagden, ed. (Cambridge: Cambridge University Press, 1991).

3 This builds on Allen Buchanan's remedial account of the right of secession in Secession: The Morality of Political Divorce from Fort Sumter to Lithuania and Quebec (Boulder: CO: Westview Press, 1991), though it adds the case of persistent minorities to the list of injustices to be remedied.

4 See James Anaya, Indigenous Peoples in International Law (Oxford: Oxford University Press, 2004). 
thought is that the replacement of unjust treatment with just treatment should have priority. The passage of generations tends to make the concern for historical injustice fade if, in the intermediate period, justice has replaced injustice. The very bad treatment of Southern and Eastern European migrants to America in the $19^{\text {th }}$ and early $20^{\text {th }}$ centuries does not seem to call for claims of rectification largely because it has been replaced by reasonably just treatment. On the other hand the appalling historical injustices meted out to Native Americans and African-Americans do suggest the need for rectification, but it is hard to separate out this concern from the fact that so much contemporary injustice and misery is imposed on these people. Were these latter problems overcome my guess is that we would lose a lot of the interest in rectification of the past.

\section{Democracy and the Global Order}

I agree entirely with Holder that the question of the legitimacy of democracy in relation to those outside the democratic community is an important one. And I think that the idea of public equality can supply some guidance in this regard. It can do so in a number of distinct ways. First, as Holder notes, to the extent that a society is reasonably democratic and thus reasonably satisfies public equality, outsiders have duties to respect the decisions that are made on the grounds that those decisions reflect the interests of the members of the society. And there is in this an egalitarian component as well, to the extent that the interests of the members are of equal importance to those of the outsiders. Second, there is another more subtle way in which public equality has importance. The view of justice that I defend in chapter 1 is ultimately a cosmopolitan principle. State borders do not have ultimate moral significance. In my view, the ultimate political aspiration of the moral cosmopolitan must be a global political community. Contemporary political communities are simply limited efforts to achieve justice among persons. The limits make sense for a variety of reasons of expedience. But the limits are ultimately to be breached in favor of regional organizations and finally in favor of global organization. Despite this, I think it would be a deeply unwise move to undermine or even ignore the limited justice that has been achieved in geographically limited societies for the sake of what is at the moment a merely speculative gain for the world. The limited justice of contemporary political societies must be seen in part as among the seeds of a more global scheme of justice for the future.

Third, the principle of public equality can extend, I think to the global realm. There is a sense in which one can treat persons publicly as equals or inferiors in the global system. Obviously conquest and imperialism are key instances of this public treatment of persons as inferiors. But I also think that certain blatant cases of unfair advantage taking of some societies by others are instances of this. And I think that Canadians or Mexicans or Europeans can and ought to have some say in what happens in the United States. For 
the moment though, given the centrality of the state in the international order and the importance of states in creating large-scale accountability of legal and political organizations to persons, the way Europeans have an influence on Americans is through international negotiation between the states. To the extent that the Canadian government represents its citizens in the process of negotiation with Americans, the citizens can have a kind of say in what happens in the United States. Of course this is on condition that the governments are in fact representative and that the processes of negotiation do not involve unfair advantage taking. My sense - though this remains pretty speculative - is that the principle of public equality can give us some guidance in characterizing both the requisite form of representation and the proper notion of unfair advantage taking, and it can thereby give guidance in characterizing fair negotiation among states. ${ }^{5}$

\section{C.L. Ten's Comments}

C.L. Ten articulates a number of worries after giving an admirably clear account of my conception of democratic authority. Mainly, I think he is concerned that my account of democracy does not really argue for democracy at all.

\section{Democracy, Autocracy and Injustice}

I will start with the main body of concerns. To start with, Ten thinks that my account of how the existence of persistent minorities undercuts democratic authority suggests that major injustices to vulnerable groups can weaken democratic authority. This might suggest that democracy is to be evaluated entirely in terms of outcomes. And if very bad outcomes defeat the authority of democracy generally, then it is not clear what kind of inherent authority it can have.

In response to this concern, I should say a little about how I conceive of the problem of permanent minorities in relation to democratic authority. I sketched above my conception of how democratic authority is undercut by violations of public equality. Now I take the existence of a persistent minority to be a violation of public equality. For there to be a persistent minority, there must be a group of significant size that never or almost never gets its way in elections or voting. Usually this is because society is divided into discrete and insular groups that share very little in terms of preferences and are such that one group can always win out in majority voting without having to compromise with the other. The argument for the thesis that the presence of

5 I lay out some of the rudiments of a conception of fair international negotiation in my "Democratic Legitimacy and International Institutions," in The Philosophy of International Law, Samantha Besson and John Tasioulas, eds. (Oxford: Oxford University Press, 2010). 
a persistent minority violates public equality is that the persistent minority in effect lacks the means for affecting law and policy. My thought is that the very same interests that ground our concern for each person having a say in the society - namely correcting for cognitive bias, being at home in the world and being affirmed as an equal - are set back for the permanent minority. To the extent that this is so, the considerations that lead us to think that a nondemocratic form of decision-making may violate public equality should also lead us to think that the existence of a persistent minority violates public equality. If all of this is correct, then the existence of a permanent minority undercuts the authority of the democratic assembly. I argue that every significant group must have some minimum of input in order for this authority not to be undercut. This is a limit to the inherent authority of democracy but it is meant still to allow for the legitimation of a wide variety of incompatible outcomes and thereby leaves room for significant disagreement about justice, even major injustices, as long as they do not reach to the level of public inequality. Public mistreatment of persons undercuts the authority of democracy; major injustices, if they are not public inequality, do not.

I think that publicly clear inequality does undercut the inherent authority of democracy but it does not follow from this that we should prefer nondemocratic institutions in cases where democracy persistently violates public equality. The judgment here must be comparative and empirically based. There must be good reason to think that the non-democratic institution will not violate public equality nearly as much, or so I argue. And it seems to me that there is a growing body of evidence, the arguments of Fareed Zakaria and Amy Chua notwithstanding, ${ }^{6}$ that robust democracies with high levels of participation and competition among different groups do significantly better in protecting basic rights than authoritarian states and weaker democracies.7 The evidence increasingly suggests that liberal authoritarian states, like decent consultation hierarchies, are social and political anomalies; authoritarian and hierarchical states simply cannot be relied upon to protect basic rights. So though some robust democracies may not protect basic rights as well as we might wish, the alternative is usually much worse. The reason for this is central to the claims of my book. If there is a risk of the majority violating the rights of the minority, it is hard to see how this will be remedied in a reliable way by giving power to an even smaller minority. These kinds of results

${ }^{6}$ See Amy Chua, World on Fire: How Exporting Free Market Democracy Breeds Ethnic Hatred and Global Instability (New York: Anchor Books, 2004) and Fareed Zakaria, The Future of Freedom: Illiberal Democracy at Home and Abroad (Norton, New York, 2003).

7 Two recent and important papers in this area are Christian Davenport and David A. Armstrong, II, "Democracy and the Violation of Human Rights: A Statistical Analysis from 1976 to 1996," American Journal of Political Science, Vol. 48, No. 3 (July 2004), pp. 538-554. See also, Bruce Bueno de Mesquita, G. W. Downs, A. Smith and F. M. Cherif, "Thinking Inside the Box: A Closer Look at Democracy and Human Rights," International Studies Quarterly 49 (3) 2005: 439-57. For a fuller discussion, see Christian Davenport, State Repression and the Domestic Democratic Peace (Cambridge: Cambridge University Press, 2007). 
should also make us cast a skeptical eye on those non-democratic institutions that check democratic institutions. It seems to me that we have reason to think that the thing that most reliably tempers the use of highly controversial views in politics is democracy itself. The need to appeal to others with different views in order to get any legislation passed tends to filter out the worst abuses. This filter does not always work but it is probably the best we have. We should tread very carefully when we start looking for non-democratic ways of limiting democracy, though sometimes they will work.

Still, I accept that some non-democratic institutions may be necessary to a fully justified democratic society. I argue that there may be a justification for having judicial review when such an institution is more likely to protect certain basic rights implied by the principle of public equality than democracy unaided by such an institution. The argument would have to be instrumental and comparative, as I argue in my book.

The result of my arguments, Ten rightly notes, is that we cannot conclude that we ought to have democracy just from the fact that democracy is intrinsically valuable. It must also be the case, for the argument for democracy to go through in a particular instance, that the exercise of democratic rights will not lead to a great deal of severe injustice and that non-democratic institutions will do a much better job on this score. Hence, I argue that, though the value of democracy is intrinsic, it is also conditional on the democracy's respect for the principle that underpins its intrinsic value: the principle of public equality. And if we need non-democratic institutions to limit democracy in order to achieve this result, then I think those limits are justified. Normally those institutional limitations will only have to be quite minimal because much of the substance of democratic decision-making does not implicate the basic liberal rights or the right to an economic minimum and it does not normally produce permanent minorities. Only in the case of the most severe, widespread and unavoidable violations of these rights would the authority of democracy be defeated in toto.

But the most important answer to this challenge is that the elements of liberal democracy, as a matter of empirical fact, seem to tend to be mutually supporting, in addition to the fact that they share a common ground in the principle of public equality.

Thomas Christiano

University of Arizona, Department of Philosophy

Princeton University Visiting Fellow

thomasc@u.arizona.edu

tc2@princeton.edu 